\title{
Nostalgia and Culture: The Relationship Between Indicators of Acculturation and Nostalgia
}

\author{
Borsali Awicha Amina ${ }^{1}$ \\ University of TLEMCEN ALGERIA \\ Email:mina.benosman@gmail.com \\ Pr Benhabib Abderrezak ${ }^{2}$ \\ University of TLEMCEN ALGERIA \\ Email: abenhabib1@yahoo.fr
}

Received: 20 February 2018/ Revised: 27 April 2018/ Accepted: 2 May 2018/Published online: 30 May 2018

\begin{abstract}
In this article we test the relationship between indicators of acculturation (language, media, selfidentification, religion, food and clothing) and nostalgia. It checks empirically, on a sample of 201, the existence of a significant effect between our independent variables and our dependent variable. The results of analysis of variance, One-Way Anova, reveal that the home language, the food of home country, the media, self-identification with the origin country and the religion of the origin country have a significant impact on nostalgia. This article contributes to new theoretical elements in the field of nostalgia and culture as a complement of several previous studies. The managerial contributions of this study focus on positioning of nostalgic brands and developing marketing strategies for this kind of products.
\end{abstract}

JEL classification: M30, M31

Keywords: nostalgic brands, positioning, acculturation.

\section{INTRODUCTION}

Today, the concept of nostalgia has become a topic of growing importance and interest to many researchers in marketing. Indeed, nowadays, many practitioners emphasize the usefulness and importance of nostalgia in segmentation and other marketing strategies. Therefore, many research works today attempt to measure the phenomenon of nostalgia. The best-known research on the topic includes Holbrook's nostalgia index (Holbrook, 1990), which is considered a benchmark in the field, and Batcho's inventory (Batcho, 1995). These two essential tools are Anglo-Saxon scales that measure the nostalgic mood. The first study was carried out by Holbrook and Schindler (1989) on the relationship between nostalgia and musical preferences. Next, Holak and Havlena (1992) investigated the nostalgic emotional experience, then Baker and Kennedy (1994) conducted a study on the intensity of nostalgia vis-a-vis advertisement, and finally Sedikides, Wildschut,

Professor in Economics, Management and Management Science, Director of the MECAS laboratory 
Arndt and Routledge (2008) made an attempt to define nostalgia and to find its relationship with the past, present and future. On the other hand, it is worth recalling that most of this research was conducted at Southampton University (Great Britain), where a whole research program is devoted to nostalgia. Every year, an appreciable number of new articles are published in this area. Nostalgia is also a fairly popular area of research in France. Indeed, Aurélie Kessous and Elyette Roux are considered pioneers in the field of nostalgia in France. They have conducted numerous studies, especially on brands perceived as nostalgic (Kessous \& Roux, 2010). Other researchers were interested in authenticity (Derbaix \& Derbaix, 2010), nostalgia in marketing (Robert-Demontrond \& Divard, 1997) and nostalgia in consumer behavior (Hallegate \& Marticotte, 2017). Moreover, while seeking to measure nostalgia, other practitioners, such as Kessous and Roux (2010) or Alexandra Vignolles (2009), have succeeded in developing and proposing a scale to measure the propensity to be nostalgic. However, few studies have focused on the cultural aspect of nostalgia. The most important one is that conducted by a group of researchers from 18 different countries, spread over five continents (Australia, Cameroon, Chile, China, Ethiopia, Germany, Greece, India, Ireland, Israel, Japan, the Netherlands, Poland, Romania, Turkey, Uganda, the United Kingdom, and the United States). The purpose of this international study was to find out whether people from different cultures conceive nostalgia in the same way. In the end, the researchers involved in the investigation found that nostalgia is a pancultural emotion, it is present in all cultures; nostalgia may be expressed similarly or differently, depending on the culture (Hepper et al., 2014). Researchers Havlena and Holak (2015) focused on nostalgia in Japan; they showed that, for Japanese people, nature is a trigger for nostalgia. The purpose of the present article is to provide new avenues for research on the cultural aspect of nostalgia. It is for this reason that the present study focuses on nostalgia from a different cultural point of view using indicators of acculturation (language, food, clothing, media, self-identification and religion) and testing them on the nostalgia. The present study is interesting because it provides new directions for future research in the field of nostalgia. Studying nostalgia for the expatriate segment is currently a topic of great significance. It is possible to investigate the probable link between preferences for certain things belonging to the country of origin and others related to the host country.

This study is organized as follows. The presentation of the literature review is given first, and then the methodology of work is described. Next the results obtained are presented and discussed, and finally a conclusion is given.

\section{LITERATURE REVIEW}

\subsection{Concepts of Nostalgia}

Nostalgia comes from the Greek words nostos (back home or home) and algos (pain). The concept of nostalgia is old as it goes back to Johannes Hofer (1934), who described it as a disease or pathology which may be attributed to homesickness (Bolzinger, 1989). Afterwards, definitions of nostalgia quickly evolved. Indeed, according to Holbrook (1991), nostalgia is commonly defined as a preference, a favorable link, a positive attitude, a favorable affect towards objects, people, places or things which were shared by many individuals (popular, in fashion, or widely available) when they were younger (adolescence, childhood or even before birth). It is also considered a double-sided emotion (Bellelli, 1991). For example, the emotion of memory is a situation where the individual relives his memories through his thoughts; it is also the emotion of desire and absence where the individual is aware that certain events and emotions of the past cannot be reached (or relived) again. According to Baker and Kennedy (1994), different levels of nostalgia exist. Some of these are: 
- Real nostalgia, which is marked by a direct experience lived by an individual, like a song or an object of the time of high school.

- Simulated nostalgia, which is a kind of nostalgia where the individual has no direct experience with it as a retro object of a time that he did not experience.

- Collective nostalgia, which is a nostalgia that is proper to a culture or a generation, like a sport, a flag, etc.

On the other hand, nostalgia can be real, simulated or collective; it is triggered by different stimuli, such as music (Holbrook, 1993) or smells (Hirsch, 1992), that may be sensorial and/ or intangible; they can also be tangible, just like the visual representations of timeless icons (Havlena \& Holak, 1996), food products (Baker et al., 2005), and old brands (Kessous \& Roux, 2010). The stimulus of the iconic brands of our childhood is the most widespread because today many products of our childhood can be found on the market. Currently, marketers attach great importance to nostalgic emotions and feelings in their marketing activities (Divard \& RobertDemontrond, 1997). Nostalgia can be useful in brand or product strategies; it can also be part of the positioning of the marketing mix (brand name, packaging, communication, etc.). It can also be present in a brand's advertising communications plans and may be included in various elements such as music, slogans, jingles, or images. Nostalgia is also used to relive or reintroduce older products in the market, which means that it can be used for tactical or strategic purposes according to the needs of marketing managers (Divard \& Demontrond, 1997).

\subsection{Concepts of Acculturation}

In general, acculturation refers to "the changes in attitudes, values or behaviors that members of a cultural group manifest when they are inspired by the standards or another culture, of another group" (Jolibert \& Benabdallah, 2009). Other authors define this concept as "the general process of intercultural contacts and their results" (Berry et al., 2006). It is obvious that the greater the contact, the better the acculturation (O'Quinn, Lee, \&Faber, 1986). Thus, acculturation can be seen as a process of adaptation to a different environment, or to a different country. A great deal of research has focused on acculturation and consumption. Some researchers concentrated on decision-making (Dato-on, 2000), and others on the perception of advertising and product attributes (Khairullah \&Khairullah, 1999) or on price negotiation (Nyer \& Gopinath, 2001). This study focuses on nostalgic behaviors. Previous studies have indicated that people who are less adapted to their host culture and very attached to their home culture are often nostalgic (Stamboli, 2011), because nostalgia is a way for people to show their attachment to their country of origin (Jolibert \& Benabdallah, 2011). Therefore, it would be interesting for marketers to offer products and services that can help maintain the connection with the country of origin. They can also identify the favorite media of expatriates; they may use beliefs (religion and halal products) and cultural heritage such as music, exploit values or emotional attachment of the individual to his country of origin (Jolibert \& Benabdallah, 2013). In order to measure acculturation, it is important to consider the home culture and host culture of the individual. For this, researchers have developed several indicators (Jolibert \& Benabdallah, 2009), some of which are:

- The preference for the native language compared to the language of the host country: Researchers try to find out which language the expatriates speak every day, at work or with friends and family. Acculturated people tend to use the host language a lot more.

- Food: This is an indicator of acculturation. Indeed, individuals who prefer dishes from their home countries are not very acculturated.

- The media: Marketers who know the favorite media of an expatriate can adapt the appropriate communication and choose the type of strategy to use to target their customers.

- The choice of attributes of a product: Some examples are music, cars, movies, etc. 
- Self-identification: This should result in the adoption of certain ethnic customs. Acculturated people identify more with their host country.

Acculturation, which is an important phenomenon in consumer behavior, has become an essential segmentation criterion in marketing strategies for many products and services.

\subsection{Purpose of the Study}

Today, people adopt different modes of consumption due to changes in tastes and to geographical displacements (Sayre, 1994). But nostalgia is also one of the causes of these many changes in consumption patterns. This hypothesis is to be proven later. In fact, moving from one country to another induces a change in certain preferences. Therefore it would be interesting to understand this change through nostalgia, especially now that the percentage of the immigrant population is continually increasing in the world. The purpose of this research is to study the relationship between indicators of acculturation and nostalgia in order to highlight some characteristics of the marketing concept which, to our knowledge, have never been studied before. Thus, it would be interesting to separate the acculturation indicators of the host country from those of the country of origin and then to test them on nostalgia (Appendix A).

\section{METHODOLOGY OF THE STUDY}

\subsection{Measurement of Variables}

- Acculturation: it was decided to use the Jolibert and Benabdallah (2009) scale, which has been tested on Algerian immigrants in France. This scale is interesting for our study because it allows highlighting the cultural differences which can be grouped under different items, namely language, media, self-identification, religion, clothing and food.

- Nostalgia: it was evaluated with the scale of Alexandra Vignolles (2009), who gathered many definitions of nostalgia.

- Regret: which represents the negative side of nostalgia, as proposed by Perrusson (2003).

- Nostalgia as comfort: which, according to Sedikides et al. (2004), allows individuals to give reassurance to themselves.

- A lack related to childhood: heroes and heroines, games and toys, shows, like the inventory previously proposed by Batcho (1995).

- Products of the past: which make an individual feel nostalgic when he consumes a product related to the past.

- Rituals and traditions: are important because they represent everything that brings us closer to our family, our friends, our communities or our country (Havlena \& Holak, 1996).

- Attachment to the past: nostalgia is the link that exists between the individual and the events of his past, it helps to build one's identity and an image of oneself.

\subsection{Method of Data Collection}

\section{Sampling}

The questionnaire used is composed of two parts. The first one is an assessment of acculturation variables using a Likert scale of 5 points that ranges from "strongly disagree" to "strongly agree". The second part gives an evaluation of the variable nostalgia; this is done using another Likert scale of 5 points that goes from "strongly disagree" to "strongly agree".

The questionnaire was distributed to expatriates in France, in dedicated sites. A total number of 102 questionnaires were analyzed. Our sample was composed mainly of men (63.7\%), with 
young people between 20 and 29 years old (45.1\%) and the rest between 30 and 39 years old $(27.5 \%)$. It is important to note that all individuals in the sample come from Maghreb countries, namely Algeria (32.4\%), Morocco (5.9\%), also Cameroun and Canada (6.9\%).

Table 1

Age

\begin{tabular}{|l|c|c|c|c|c|c|c|}
\multicolumn{1}{c|}{ Age } & $\mathbf{2 0 - 2 9}$ & $\mathbf{3 0 - 3 9}$ & $\mathbf{4 0 - 4 9}$ & $\mathbf{5 0 - 5 9}$ & $\mathbf{6 0 - 6 9}$ & $\mathbf{7 0 - 7 9}$ & total \\
\hline Effective numbers & 46 & 28 & 16 & 9 & 2 & 1 & 102 \\
\hline Percentages & $45.1 \%$ & $27.5 \%$ & $15.7 \%$ & $8.8 \%$ & $2 \%$ & $1 \%$ & $100 \%$ \\
\hline
\end{tabular}

Table 2

Gender

\begin{tabular}{l|ccc}
\multicolumn{1}{c}{ Gender } & Men & Women & Total \\
\hline Effective numbers & 65 & 37 & 102 \\
\hline Percentages & $63.7 \%$ & $36.3 \%$ & $100 \%$ \\
\hline
\end{tabular}

Table 3

Native country

\begin{tabular}{|c|c|c|}
\hline Home country & Effective numbers & Percentages \\
\hline Afghanistan & 1 & $1 \%$ \\
\hline Algeria & 33 & $32.4 \%$ \\
\hline Brazil & 1 & $1 \%$ \\
\hline Bulgaria & 3 & $2.9 \%$ \\
\hline Cameroon & 7 & $6.9 \%$ \\
\hline Caribbean & 1 & $1 \%$ \\
\hline China & 1 & $1 \%$ \\
\hline Congo & 1 & $1 \%$ \\
\hline North Korea & 1 & $1 \%$ \\
\hline Egypt & 1 & $1 \%$ \\
\hline Spain & 3 & $2.9 \%$ \\
\hline Canada & 7 & $6.9 \%$ \\
\hline Ghana & 1 & $1 \%$ \\
\hline Guadeloupe & 1 & $1 \%$ \\
\hline Iran & 1 & $1 \%$ \\
\hline Italy & 2 & $2 \%$ \\
\hline Lebanon & 4 & $3.9 \%$ \\
\hline Mali & 2 & $2 \%$ \\
\hline Morocco & 6 & $5.9 \%$ \\
\hline Pakistan & 2 & $2 \%$ \\
\hline Peru & 1 & $1 \%$ \\
\hline Portugal & 3 & $2.9 \%$ \\
\hline Romania & 5 & $4.9 \%$ \\
\hline Russia & 1 & $1 \%$ \\
\hline Tunisia & 5 & $4.9 \%$ \\
\hline USA & 1 & $1 \%$ \\
\hline Vietnam & 1 & $1 \%$ \\
\hline Zambia & 3 & $3 \%$ \\
\hline Zimbabwe & 3 & $3 \%$ \\
\hline Total & 102 & $100 \%$ \\
\hline
\end{tabular}




\section{RESULTS}

\subsection{Descriptive Statistics}

In this part, we describe our research sample in terms of descriptive statistics for which we used the SPSS package.

\section{Figure 1}

Home language/ the language of the host country

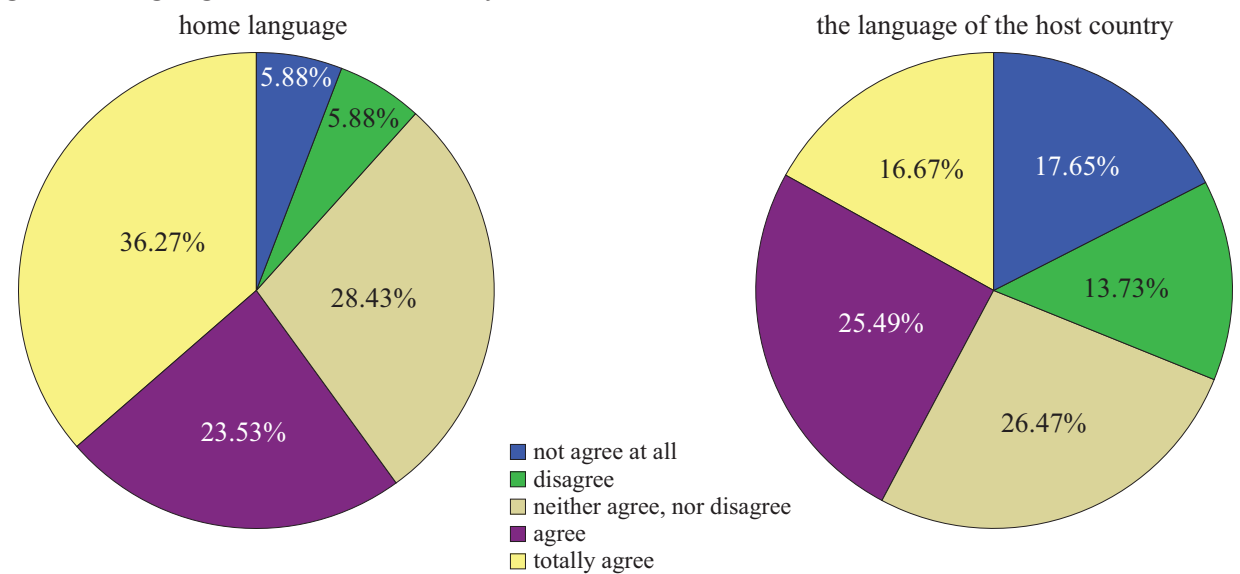

Figure 1 shows that most of our respondents practice the language of their country of origin with their family or friends. But we also see that the language of the host country is also used but in a more moderate way than the language of origin.

\section{Figure 2}

The food of home country/ the host country's food
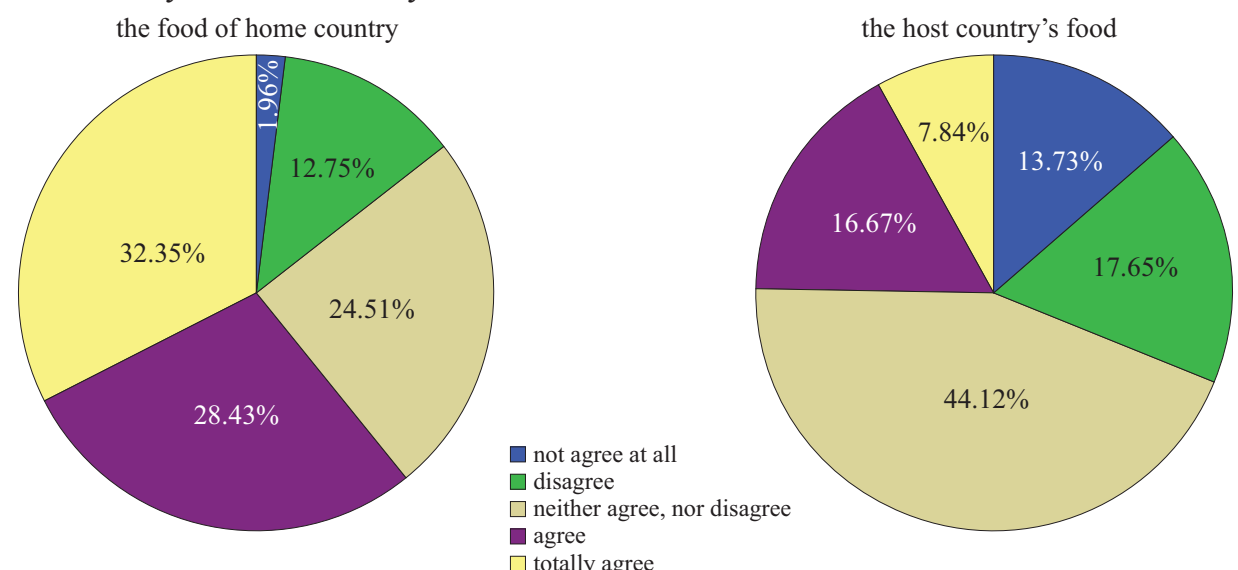

In Figure 2, the diagrams show that respondents are more attracted to the food of their origin than the food of the host country. 


\section{Figure 3}

Media



We observed in Figure 3 that expatriates use the media to learn about their culture and country of origin.

\section{Figure 4}

The clothing of the country of origin/ the clothing oh the host country

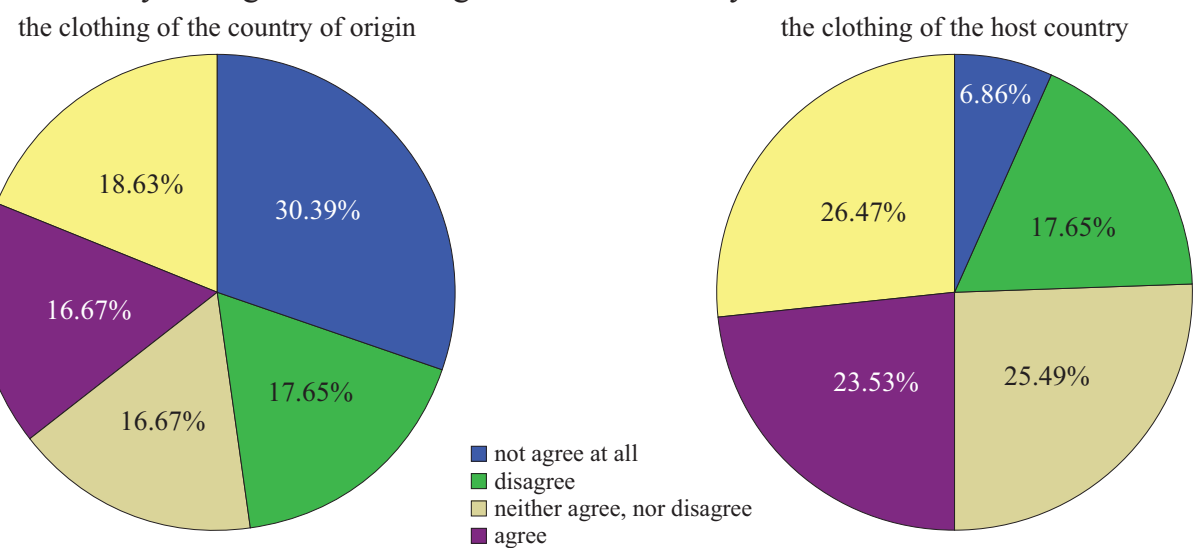

neither agree, nor disagree

$\square$ totally agree

Unlike the other variables, we see in Figure 4 that respondents follow rather the fashion of the host country than that of their country of origin.

\section{Figure 5}

Self-identification to the origin country/ Self-identification to the host country

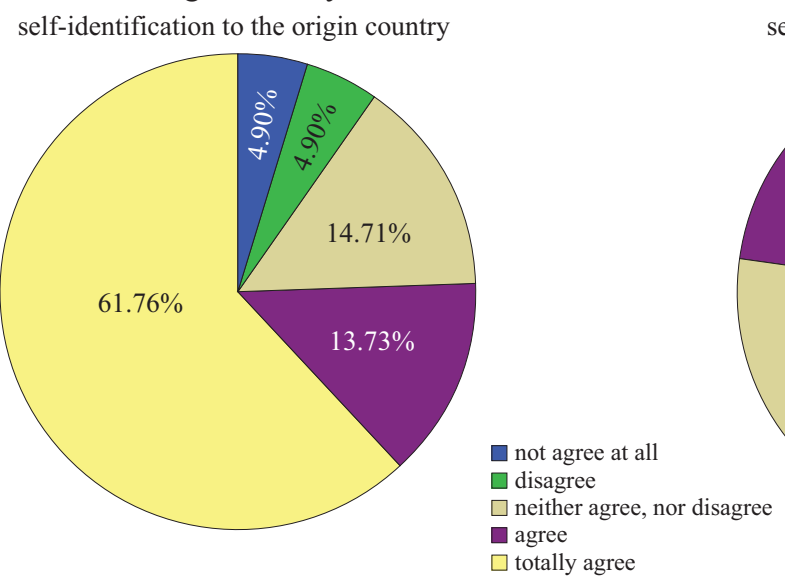

self-identification to the host country

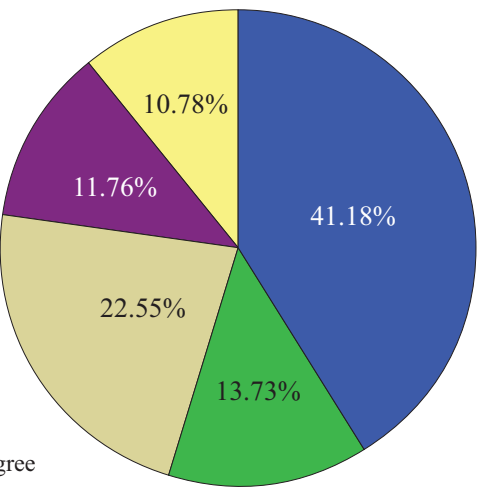

$\square$ agree

In Figure 5, we notice that the expatriate respondents identify strongly with their country of origin and practically not with the host country. 


\section{Figure 6}

The religion of the origin country/ the religion of the host country
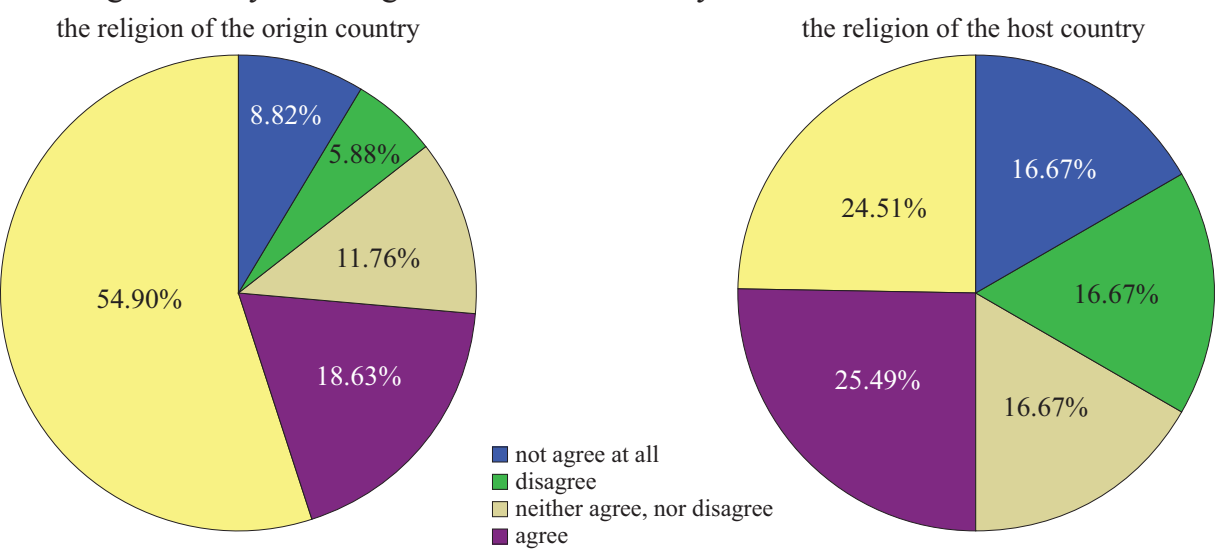

$\square$ agree

$\square$ totally agree

The diagrams in Figure 6 show that respondents celebrate the traditional festivals of their country but also those of the host country.

\section{Figure 7}

Nostalgia

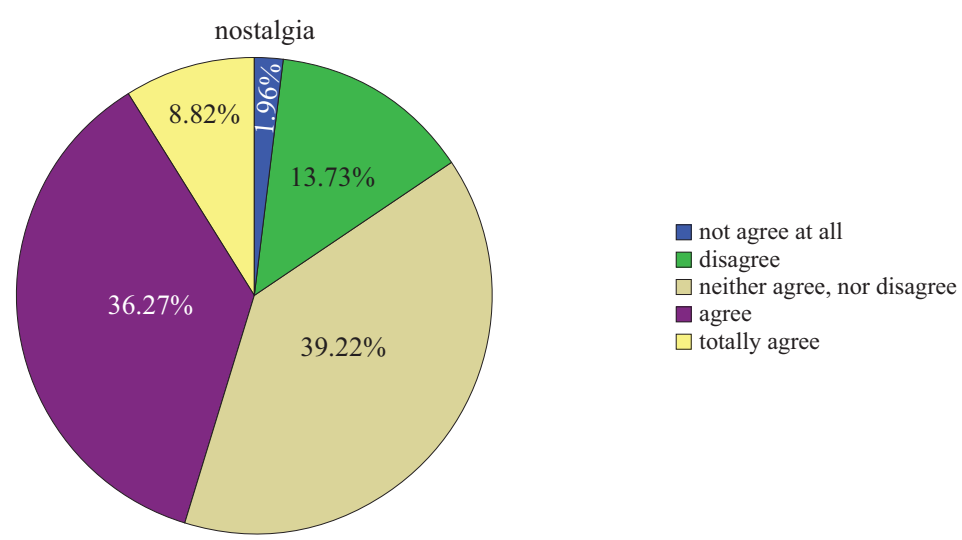

In Figure 7, most of our expatriate respondents feel nostalgia.

\subsection{Analysis of Variance: One-Way ANOVA}

The analysis of variance is used to check if indicators of acculturation have an effect on nostalgia. The summary of results is given in Appendix B. These results indicate that: the home language, the food of the home country, the media, self-identification with the origin country, and the religion of the origin country have a significant effect on nostalgia, and that the language of the host country, the food of the host country, self-identification with the host country, the clothing of the host country and the religion of the host country do not have an effect on nostalgia.

One-way Anova is done in two steps:

1) Levene homogeneity test: the Levene test must be $>0.05$; if this is the case, the homogeneity assumption is accepted. Therefore, we can analyze the results of the ANOVA.

2) In the analysis of variance we have two hypotheses:

H0: There is no significant difference between averages.

H1: There is a significant difference between the average results of nostalgia and the different groups created on the basis of the answer to questions about the inducers of acculturation.

$\mathrm{P}$ must be as small as possible, the significance level is always set at $\mathrm{p}<0.05$.

If $\mathrm{P}$ is significant, the null hypothesis is rejected. 
Table 4

Home language / nostalgia

\begin{tabular}{|c|c|c|c|}
\multicolumn{3}{c|}{ Test of homogeneity of variances } \\
\hline \multicolumn{3}{|c|}{ Nostalgia } \\
\hline Levene statistics & df1 & df2 & Sig \\
\hline 1.951 & 8 & 93 & .061 \\
\hline
\end{tabular}

The Levene test is significant $(0.061>0.05)$ and the hypothesis of homogeneity of the samples is accepted. We can analyze the results of the ANOVA.

\begin{tabular}{|c|c|c|c|c|c|}
\hline \multicolumn{6}{|c|}{ Anova } \\
\hline \multicolumn{6}{|c|}{ Nostalgia } \\
\hline & Sum of squares & df & Mean squares & $\mathbf{F}$ & Sig \\
\hline Between groups & 15.277 & 8 & 1.910 & 2.784 & .008 \\
\hline Within groups & 63.804 & 93 & .686 & & \\
\hline Total & 79.081 & 101 & & & \\
\hline
\end{tabular}

Here the averages are very different $(\mathrm{F}=2.78, \mathrm{p}=0.008<0.05)$. The null hypothesis is rejected, there is a significant difference between the average results of nostalgia and the different groups created on the basis of the answer to the question on the state of the language of origin. Therefore, individuals who speak and practice their native language have a higher average level of nostalgia than those who practice the host language.

Table 5

The language of the host country / nostalgia

\begin{tabular}{|c|c|c|c|}
\hline \multicolumn{4}{|c|}{ Test of homogeneity of variances } \\
\hline \multicolumn{4}{|c|}{ Levene statistics } \\
\hline & df1 & df 2 & Sig \\
\hline .837 & 8 & 93 & .572 \\
\hline
\end{tabular}

The Levene test is significant $(0.572>0.05)$ and the sample homogeneity assumption is accepted. We can analyze the results of the ANOVA.

\begin{tabular}{|c|c|c|c|c|c|}
\hline \multicolumn{6}{|c|}{ Anova } \\
\hline \multicolumn{6}{|c|}{ Nostalgia } \\
\hline & Sum of squares & df & Mean squares & $\mathbf{F}$ & Sig \\
\hline Between groups & 3.662 & 8 & .458 & .565 & .804 \\
\hline Within groups & 75.419 & 93 & .811 & & \\
\hline Total & 79.081 & 101 & & & \\
\hline
\end{tabular}

The averages are $(\mathrm{F}=0.56, \mathrm{p}=0.804>0.05)$. The null hypothesis is accepted, there is no significant difference between means. 
Table 6

The food of home country / nostalgia

\begin{tabular}{|c|c|c|c|}
\hline \multicolumn{3}{|c|}{ Test of homogeneity of variances } \\
\hline \multicolumn{3}{|c|}{ Nostalgia } \\
\hline Levene statistics & df1 & df2 & Sig \\
\hline 1.797 & 8 & 93 & .087 \\
\hline
\end{tabular}

The Levene test is significant $(0.087>0.05)$ and the hypothesis of homogeneity of the samples is therefore accepted. We can analyze the results of the ANOVA.

\begin{tabular}{l|c|c|c|c|c|}
\hline & \multicolumn{5}{c}{ ANOVA } \\
& Sum of squares & df & Mean squares & F & Sig \\
\hline Between groups & 14.111 & 8 & 1.764 & 2.525 & .016 \\
\hline Within groups & 64.970 & 93 & .699 & & \\
\hline Total & 79.081 & 101 & & \\
\hline
\end{tabular}

The averages are $(\mathrm{F}=2.52, \mathrm{p}=0.016<0.05)$. The null hypothesis is rejected, there is a significant difference between the average results of nostalgia and the different groups created on the basis of the answer to the question on the food of the country of origin. Therefore, individuals who consume food from their home country have a higher average level of nostalgia than those who consume food from their host country.

Table 7

The host country's food

\begin{tabular}{|c|c|c|c|}
\hline \multicolumn{2}{|c|}{ Test of homogeneity of variances } \\
\hline \multicolumn{3}{|c|}{ Nostalgia } \\
\hline Levene statistics & fd1 & df2 & Sig \\
\hline 1.651 & 8 & 93 & .121 \\
\hline
\end{tabular}

The Levene test is significant $(0.121>0.05)$ and the hypothesis of homogeneity of the samples is therefore accepted. We can analyze the results of ANOVA

\begin{tabular}{|c|c|c|c|c|c|}
\hline \multicolumn{6}{|c|}{ ANOVA } \\
\hline \multicolumn{6}{|c|}{ Nostalgia } \\
\hline & Sum of squares & df & Mean squares & $\mathrm{F}$ & Sig \\
\hline Between groups & 6.712 & 8 & .839 & 1.078 & .385 \\
\hline Within groups & 72.369 & 93 & .778 & & \\
\hline Total & 79.081 & 101 & & & \\
\hline
\end{tabular}

The averages are $(\mathrm{F}=1.07, \mathrm{p}=0.385>0.05)$. The null hypothesis is accepted, there is no significant difference between means. 
Table 8

Media / nostalgia

\begin{tabular}{|c|c|c|c|}
\hline \multicolumn{2}{c|}{ Test of homogeneity of variances } \\
\hline \multicolumn{3}{|c|}{ Nostalgia } \\
\hline Levene statistics & df1 & df2 & Sig \\
\hline .667 & 12 & 89 & .779 \\
\hline
\end{tabular}

The Levene test is significant $(0.779>0.05)$ and the hypothesis of homogeneity of the samples is therefore accepted. We can analyze the results of ANOVA

\begin{tabular}{lcrccc} 
& \multicolumn{5}{c}{ ANOVA } \\
& \multicolumn{5}{c}{ Nostalgia } \\
& Sum of squares & df & Mean squares & F & Sig \\
\hline Between groups & 18.247 & 12 & 1.521 & 2.225 & .017 \\
Within groups & 60.834 & 89 & .684 & & \\
Total & 79.081 & 101 & & &
\end{tabular}

The averages are $(\mathrm{F}=2.22, \mathrm{p}=0.017<0.05)$. The null hypothesis is rejected, there is a significant difference between the average results of nostalgia and the different groups created on the basis of the answer to the question on the use of the media concerning their country of origin. Therefore, individuals who use the media to learn about their country of origin have a higher average level of nostalgia than those who do not use them.

Table 9

The clothing of the country of origin / nostalgia

\begin{tabular}{|c|c|c|c|}
\hline \multicolumn{4}{|c|}{ Test of homogeneity of variances } \\
\hline \multicolumn{4}{|c|}{ Nostalgia } \\
\hline Levene statistics & df1 & df2 & Sig \\
\hline 3.688 & 4 & 97 & .008 \\
\hline
\end{tabular}

The Levene test is significant $(0.008<0.05)$ and the hypothesis of homogeneity of the samples is rejected. We cannot analyze the results of the ANOVA.

Table 10

The clothing of the host country / nostalgia

\begin{tabular}{|c|c|c|c|}
\hline \multicolumn{3}{|c|}{ Test of homogeneity of variances } \\
\hline \multicolumn{3}{|c|}{ Nostalgia } \\
\hline Levene statistics & df1 & df2 & Sig \\
\hline .848 & 8 & 93 & .563 \\
\hline
\end{tabular}

The Levene test is significant $(0.563>0.05)$ and the hypothesis of homogeneity of the samples is therefore accepted. We can analyze the results of ANOVA 


\begin{tabular}{|c|c|c|c|c|c|}
\hline \multicolumn{6}{|c|}{ ANOVA } \\
\hline \multicolumn{6}{|c|}{ Nostalgia } \\
\hline & Sum of squares & df & Mean squares & $\mathbf{F}$ & Sig \\
\hline Between groups & 6.747 & 8 & .843 & 1.084 & .381 \\
\hline Within groups & 72.334 & 93 & .778 & & \\
\hline Total & 79.081 & 101 & & & \\
\hline
\end{tabular}

The averages are $(\mathrm{F}=1.08, \mathrm{p}=0.381>0.05)$. The null hypothesis is accepted, there is no significant difference between means.

Table 11

Self-identification with the origin country / nostalgia

\begin{tabular}{|c|c|c|c|}
\hline \multicolumn{3}{|c|}{ Test of homogeneity of variances } \\
\hline \multicolumn{3}{|c|}{ Nostalgia } \\
\hline Levene statistics & df1 & df2 & Sig \\
\hline .465 & 4 & 97 & .761 \\
\hline
\end{tabular}

The Levene test is significant $(0.761>0.05)$ and the hypothesis of homogeneity of the samples is therefore accepted. We can analyze the results of ANOVA

\begin{tabular}{|c|c|c|c|c|c|}
\hline \multicolumn{6}{|c|}{ ANOVA } \\
\hline \multicolumn{6}{|c|}{ Nostalgia } \\
\hline & Sum of squares & df & Mean squares & $\mathbf{F}$ & Sig \\
\hline Between groups & 22.069 & 4 & 5.517 & 9.387 & .000 \\
\hline Within groups & 57.013 & 97 & .588 & & \\
\hline Total & 79.081 & 101 & & & \\
\hline
\end{tabular}

The averages are $(\mathrm{F}=9.38, \mathrm{p}=0.000<0.05)$. The null hypothesis is rejected; there is a significant difference between the average results of nostalgia and the different groups created on the basis of the answer to the question on identification at country of origin. Therefore, individuals who identify with their country of origin have a statistically higher average level of nostalgia than those who identify with their host country.

Table 12

Self-identification to the host country / nostalgia

\begin{tabular}{|c|c|c|c|}
\hline \multicolumn{4}{|c|}{ Test of homogeneity of variances } \\
\hline \multicolumn{4}{|c|}{ Nostalgia } \\
\hline Levene statistics & df1 & df 2 & Sig \\
\hline 2.351 & 4 & 97 & .059 \\
\hline
\end{tabular}

The Levene test is significant $(0.059>0.05)$ and the homogeneity assumption of the samples is accepted. We can analyze the results of ANOVA 


\begin{tabular}{l|c|c|c|c|c|}
\hline & \multicolumn{5}{c}{ ANOVA } \\
& \multicolumn{7}{c|}{ Nostalgia } \\
& Sum of squares & df & Mean squares & F & Sig \\
\hline Between groups & 4.437 & 4 & 1.109 & 1.441 & .226 \\
\hline Within groups & 74.644 & 97 & .770 & & \\
\hline Total & 79.081 & 101 & & \\
\hline
\end{tabular}

The averages are $(\mathrm{F}=1.44, \mathrm{p}=0.226>0.05)$. The null hypothesis is accepted, there is no significant difference between means.

Table 13

The religion of the origin country / nostalgia

\begin{tabular}{|c|c|c|c|}
\hline \multicolumn{3}{c|}{ Test of homogeneity of variances } \\
\hline \multicolumn{3}{|c|}{ Nostalgia } \\
\hline Levene statistics & df1 & df2 & Sig \\
\hline 1.982 & 4 & 97 & .103 \\
\hline
\end{tabular}

The Levene test is significant $(0.103>0.05)$ and the hypothesis of homogeneity of the samples is therefore accepted. We can analyze the results of ANOVA.

\begin{tabular}{|c|c|c|c|c|c|}
\hline \multicolumn{6}{|c|}{ ANOVA } \\
\hline \multicolumn{6}{|c|}{ Nostalgia } \\
\hline & Sum of squares & df & Mean squares & $\mathbf{F}$ & Sig \\
\hline Between groups & 15.747 & 4 & 3.937 & 6.029 & .000 \\
\hline Within groups & 63.335 & 97 & .653 & & \\
\hline Total & 79.081 & 101 & & & \\
\hline
\end{tabular}

The averages are $(\mathrm{F}=6.02, \mathrm{p}=0.000<0.05)$. The null hypothesis is rejected; there is a significant difference between the average results of nostalgia and the different groups created on the basis of the answer to the question on the religion of the country of origin. Therefore, individuals who practice the religion of their country of origin have a higher average level of nostalgia than those who practice the religion of their host country.

Table 14

The religion of the host country / nostalgia

\begin{tabular}{|c|c|c|c|}
\hline & \multicolumn{2}{c|}{ Test of homogeneity of variances } \\
\hline & \multicolumn{2}{c|}{ Nostalgia } & Sig \\
\hline Levene statistics & df1 & df2 & .062 \\
\hline
\end{tabular}

The Levene test is significant $(0.06>0.05)$ and the sample homogeneity assumption is accepted. We can analyze the results of ANOVA. 


\begin{tabular}{l|c|c|c|c|c|}
\hline & \multicolumn{9}{c}{ ANOVA } \\
& \multicolumn{7}{c}{$\begin{array}{c}\text { Nostalgia } \\
\end{array}$} & Sum of squares & df & Mean squares & F & Sig \\
\hline Between groups & 1.284 & 4 & .321 & .400 & .808 \\
\hline Within groups & 77.797 & 97 & .802 & & \\
\hline Total & 79.081 & 101 & & & \\
\hline
\end{tabular}

The averages are $(\mathrm{F}=0.40, \mathrm{p}=0.808>0.05)$. The null hypothesis is accepted, there is no significant difference between means.

\section{DISCUSSION AND MANAGERIAL IMPLICATIONS}

Acculturation is defined as the change in attitudes, values or behaviors that members of a cultural group manifest in order to be inspired by the standards of another culture (Jolibert \& Benabdallah, 2009). This concept has already been studied in the field of nostalgia. In a previous study, it was found that consumers who are least adapted to their host culture often express nostalgic feelings, particularly towards their culture of origin. This usually results in the consumption of products from their home country. Therefore, managers need to consider nostalgia in their marketing strategies by making interesting offers that help maintain and strengthen the connection with the culture of origin (Benabdallah \& Jolibert, 2013).

In our study, we investigate whether the variables of acculturation put in place by Jolibert and Benabdallah (2009) and classified according to six criteria namely language, media, selfidentification, religion; clothing and food have an impact on nostalgia.

After conducting the analysis of a one-way Anova, we reached the following conclusions:

\section{Language:}

Language is one of the indicators of culture and several studies before have proved that it is related significantly to nostalgia (Rousseau, 1999). This study indeed proves that the language of the country of origin has a significant effect on nostalgia. This is reflected in the fact that our respondents who practice the language of their home country are more often more nostalgic than those who practice only the language of the host country (the language of the host country has no impact on nostalgia).

We have proved that language is the link that unites an expatriate with his past, with his traditions, his memories, even with the bitter side of nostalgia as the regret, but it also triggers feelings of comfort.

Therefore, we suggest that managers use this option in their advertising. We can play with several elements such as music, slogans, and jingles or on the image. Some brands have already used it before on advertising posters, using a short slogan but with several languages. The goal is to create a link between the brand and the consumer by triggering a nostalgic impulse.

\section{Food:}

According to Baker et al. (2005), food and nostalgia are related through culinary recipes. As a matter of fact:

- Culinary recipes play a symbolic role in rituals; they represent the link with time and events.

- Culinary recipes strengthen family ties.

- Culinary recipes help to construct self-identity; they are linked to memorable events of childhood. Thus, it can be concluded that food and nostalgia are closely linked. 
This study shows us that the food of the home country has a significant effect on nostalgia.

Therefore, we suggest that brands use nostalgia in a more sensory way by communicating about a nostalgic food product in a different way based on other elements such as its authenticity or origin. The goal is to create physical but especially emotional proximity between the consumer and the food, like the brand "Bonne maman", which uses the option of childhood and products that used to be consumed. Others have decided to focus on the cultural origin of the food product as the "world products" rays found in supermarkets.

We also found non-significance between the host country's food and nostalgia. This proves that some expatriates are probably experiencing some lack of their original food.

\section{Media:}

The media are one of the strongest links between an expatriate and his origins. Indeed, they have a significant impact on nostalgia. In short, all indicators of acculturation. In addition, brands often use the media to promote their products. We suggest that they go through specific media that target a specific audience, like for example "Beur FM", which is a radio which targets mainly the Maghreb. The goal is to trigger a nostalgic feeling through specific media but broadcast in the host country.

\section{Clothing:}

Fashion is a more complicated concept in the field of nostalgia. Even if the Levene test was inconclusive and we were not able to perform the analysis of variance. The answers from our samples show that it is rare to see expatriates dress traditionally in everyday life. Expatriates mainly follow the fashion of the host country, even if the latter does not make them nostalgic (as evidenced by our results).

Therefore, it is interesting for brands to play the nostalgia card subtly, combining modernity and ethnicity. We can call this standardized adaptation to unconsciously trigger the nostalgic emotion among expatriates in search of connection with their childhood, their traditions and their past.

\section{Self-identification:}

According to the results, expatriates who identify with their country of origin feel more nostalgia (P significant). What makes these individuals interesting nostalgic consumers? Indeed, they will seek their identity from their cultural community, because this community will favor social connections primarily (Wildschut et al., 2010). Then we suggest using nostalgia in the virtual sphere by creating discussions on nostalgic brands to attract these cultural communities and promote interaction between them.

The results also show non-significance between self-identification with the host country and nostalgia. This proves once again that nostalgic expatriates are those who identify least with their host country and more with their roots.

\section{Religion:}

The use of the term religion in the study refers to the celebration of holidays and culture in general. The results show us that the religion of the country of origin has an impact on nostalgia.

Therefore, we suggest that managers use nostalgic brands that can trigger cultural connections. They can also use iconic and reassuring brands for the expat (Holak, 2014), or brands in connection with celebrations, parties, or with the history of the country of origin; it is important to create an affective and sentimental relationship with the brand. We can also suggest launching retro products with strong cultural roots (Kessous, 2015). Therefore, the brand will establish with the expatriate consumer a relationship of trust, which will promote his loyalty. And even if expatriates are more in touch with the religion of the host country, this one has no connection with nostalgia. 
Nostalgia is an interesting marketing tool. It gives an authentic and quality image of the brand (Sierra \& McQuitty, 2007). It also provides a sense of credibility (Merchant, LaTour, Ford, \& LaTour, 2013; Zeitlin \& Westwood, 1986). Nostalgic cultural brands are a way for the expatriate consumer to relive some important events from his past. They can be happy or sad; it is up to the brand to make sure to alleviate the sad feelings.

In the end, our results suggest that the culture of origin strongly influences the nostalgic feeling. Culture is the link with childhood, the past and traditions.

\section{CONCLUSION - LIMITS AND IMPLICATIONS FOR FUTURE RESEARCH}

First, this research contributes to answering the problem: Does acculturation of expatriates have an impact on nostalgia?

But it also contributes on different levels:

Theoretically: This study confirms and enriches the theories that have been developed on nostalgia and culture, in particular that of Kessous (2015) and his theory on the impact of culture on the attitude of consumers towards nostalgic brands. Therefore, our research follows the current and valid theories of nostalgia.

Methodologically: Culture is often observed and measured qualitatively. But in our study, it is approached differently. Indeed, we used the quantitative method. This contributed to enriching the methodology on the cultural aspect.

On the managerial level, we talked about several managerial contributions in our "discussion" part. In summary, nostalgia is a powerful sales tool. It touches the sentimental and emotional side of the consumer, and today emotional marketing is an undeniable asset for marketing.

This study has presented interesting results, but it has many limitations. First, our sample is made up of more men than women and the majority are of North African origin. Therefore, we could not do some analysis. Future research can carry out the same study but comparing men and women or cultures between people, because each culture has its traditions and its ideals. The results may be interesting in this respect. Then, collecting questionnaires from expatriates was difficult. In some places expatriates are inaccessible because of the legal laws which stipulate that surveys should not refer to ethnic origin.

In this study, we represented culture through the concept of acculturation, but culture is vast and has many facets. Future research can explore other theories like Hofstede's dimensions.

Finally, we used the scales of Jolibert and Benabdallah (2009) for acculturation and the scale of Alexandra Vignolles (2009) for nostalgia. These scales have been validated by the authors, but other scales could yield other results. It is therefore interesting for future research to create a new scale for culture and nostalgia, more current and more precise.

\section{References}

Auenbrugger, L. (1808). Nouvelle méthode pour reconnaître les maladies internes de la poitrine par la percussion de cette cavité. Meguignon-Marvis.

Batcho, K.I. (1995). Nostalgia: A psychological perspective. Perceptual and Motor Skills, 80(1), 131-143.

Belk, R.W., Wallendorf, M., \& Sherry Jr, J.F. (1989). The sacred and the profane in consumer behavior: Theodicy on the odyssey. Journal of Consumer Research, 16(1), 1-38.

Belk, R.W. (1990). The role of possessions in constructing and maintaining a sense of past. In M.E. Goldberg, G. Gorn, \& R.W. Pollay (Eds.), NA - Advances in consumer research (Vol. 17, pp. 669-676). Provo, UT: Association for Consumer Research.

Belk, R.W. (1992). Attachment to possessions. In I. Altman, \& S. M. Low (Eds.), Place attachment (pp. 37-62). Springer.

Bellelli, G. (1991). Une émotion ambiguë: la nostalgie. Cahiers Internationaux de Psychologie, 11, 59-76. 
Bolzinger, A. (1989). Jalons pour une histoire de la nostalgie. Bulletin de psychologie, 42(389), 310-321.

Robert-Demontrond, P., \& Bougeard, C. (2008). Proposition d'une échelle de mesure du degré d'enracinement d'un consommateur dans sa région (No. halshs-00359103).

Boulbry, G. (2003). L'impact du vieillissement cognitif sur l'efficacité publicitaire: le cas de la publicité à évocations nostalgiques. $\mathrm{PhD}$ thesis, Rennes 1.

Brown, B.B., \& Werner, C.M. (1985). Social cohesiveness, territoriality, and holiday decorations: The influence of cul-de-sacs. Environment and behavior, 17(5), 539-565.

Davis, F. (1979). Yearning for yesterday: A sociology of nostalgia. Free Press.

Di Méo, G. (2001). Le sens géographique des fêtes/the geographical meaning of festivities. In Annales de géographie (pp. 624-646).

Divard, R., \& Robert-Demontrond, P. (1997). La nostalgie: un thème récent dans la recherche marketing. Recherche et Applications en Marketing (French Edition), 12(4), 41-62.

Dovey, K. (1985). Home and homelessness. In Home environments (pp. 33-64). Springer.

Feldman, R.S. (1990). The social psychology of education: Current research and theory. Cambridge University Press.

Fried, M., \& Gleicher, P. (1961). Some sources of residential satisfaction in an urban slum. Journal of the American Institute of planners, 27(4), 305-315.

Guàrdia, J., \& Pol, E. (2002). A critical study of theoretical models of sustainability through structural equation systems. Environment and Behavior, 34(1), 137-149.

Hallegate, D., \& Marticotte, F. (2014). Does Holbrook's nostalgia index measure nostalgia proneness?

Havlena, W.J., \& Holak, S.L. (1991). "The good old days": Observations on nostalgia and its role in consumer behavior. Advances in consumer research, $18(1)$.

Hepper, E.G., Wildschut, T., Sedikides, C., Ritchie, T.D., Yung, Y.F., Hansen, N., \& Gebauer, J.E. (2014). Pancultural nostalgia: Prototypical conceptions across cultures. Emotion, 14(4), 733.

Hirsch, A.R. (1992). Nostalgia: A neuropsychiatric understanding. In Advances in Consumer Research (Vol. 19, pp. 390-395).

Hofer, J. (1934). Medical dissertation on nostalgia. Bulletin of the History of Medicine, 2, 376-391.

Hofstede, G., \& Bond, M.H. (1984). Hofstede's culture dimensions: An independent validation using Rokeach's value survey. Journal of cross-cultural psychology, 15(4), 417-433.

Holbrook, M.B., \& Schindler, R.M. (1991). Echoes of the dear departed past: Some work in progress on nostalgia. ACR North American Advances.

Holbrook, M.B. (1993). Nostalgia and consumption preferences: Some emerging patterns of consumer tastes. Journal of Consumer research, 20(2), 245-256.

Holbrook, M.B. (1994). Nostalgia proneness and consumer tastes. Buyer Behavior in Marketing, 2, $348-364$.

Holbrook, M.B., \& Schindler, R.M. (1996). Market segmentation based on age and attitude toward the past: Concepts, methods, and findings concerning nostalgic influences on customer tastes. Journal of Business Research, $37(1), 27-39$.

Holbrook, M.B., \& Schindler, R.M. (2003). Nostalgic bonding: Exploring the role of nostalgia in the consumption experience. Journal of Consumer Behaviour, 3(2), 107-127.

Jagannathan, M. (2005). South Indian Hindu festivals and tradition. Abhinav Publications.

Kessous, A. \&.Roux E. (2010). Les marques perçues comme «nostalgiques»: conséquences sur les attitudes et les relations des consommateurs à la marque. Recherche et Applications en Marketing (French Edition), 25(3), 29-56.

Kessous, A., \&. Roux E. (2014). Nostalgie: de l'optique des consommateurs à celle des marques/nostalgia: From the perspective of the consumers to that of brands. Décisions Marketing, 75, p. 117.

Kusumi, T., Matsuda, K., \& Sugimori, E. (2010). The effects of aging on nostalgia in consumers' advertisement processing. Japanese Psychological Research, 52(3), 150-162.

Lalli, M. (1992). Urban-related identity: Theory, measurement, and empirical findings. Journal of Environmental Psychology, 12(4), 285-303.

Legge, J. (1971). Confucian analects (trans.).

Leung, K., Bhagat, R.S., Buchan, N.R., Erez, M., \& Gibson, C.B. (2005). Culture and international business: Recent advances and their implications for future research. Journal of International Business Studies, 36(4), $357-378$.

Lewicka, M. (2005). Ways to make people active: The role of place attachment, cultural capital, and neighborhood ties. Journal of Environmental Psychology, 25(4), 381-395.

Little, J.W., III. (1987). Nipple-areolar reconstruction. Advances in Plastic and Reconstructive Surgery, 3, $43-79$.

Loveland, K.E., Smeesters, D., \& Mandel, N. (2010). Still preoccupied with 1995: The need to belong and preference for nostalgic products. Journal of Consumer Research, 37(3), 393-408. 
Low, S.M., \& Altman, I. (1992). Place attachment. In: Human Behavior and Environment book series (Hube, Vol. 12, pp. 1-12). Boston, MA: Springer. University of Utah, Salt Lake City, USA. Graduate School and University Center, City University of New York, New York USA. Springer, Boston, MA. Springer Book Archive.

McAndrew, F.T., Akande, A., Turner, S., \& Sharma, Y. (1998). A cross-cultural ranking of stressful life events in Germany, India, South Africa, and the United States. Journal of Cross-Cultural Psychology, 29(6), 717-727.

McCann, W.H. (1941). Nostalgia: A review of the literature. Psychological Bulletin, 38(3), 165.

McCracken, G. (1990). The evocative power of things: Consumer goods and the preservation of hopes and ideals. In Culture and consumption: New approaches to the symbolic character of consumer goods and activities $\left(1^{\text {st }}\right.$ Midland Book ed., pp. 104-117). Bloomington, Ind., Indianapolis, Ind.: Indiana University Press.

Moore, R.L., \& Graefe, A.R. (1994). Attachments to recreation settings: The case of rail-trail users. Leisure Sciences, $16(1), 17-31$.

Perrusson, C. (2003). Contribution à une meilleure compréhension des effets de la nostalgie évoquée dans l'annonce publicitaire: une application aux messages televises. $\mathrm{PhD}$ thesis, Paris.

Pol, E., \& Castrechini, A. (2002). City-identity-sustainability research network: Final words. Environment and Behavior, 34(1), 150-160.

Porchet, J. (1979). La nostalgie. A partir de jeunes militaries. Thesis of medicine, Lille.

Proshansky, H.M., Fabian, A.K., \& Kaminoff, R. (1983). Place-identity: Physical world socialization of the self. Journal of Environmental Psychology, 3(1), 57-83.

Rivlin, L.G. (1982). Group membership and place meanings in an urban neighborhood. Journal of Social Issues, 38(3), 75-93.

Robert-Demontrond, P., \& Boulbry, G. (2003). Marketing mémoriel: attraits et dangers du phénomène nostalgique. Gestion 2000, (2), 31-47.

Robert-Demontrond, P. (2008). Entre compromis, compromissions ou entrée en dissidence: les avenirs du commerce équitable. Décisions marketing, 27-38.

Robert-Demontrond, P. (2010). Nouveaux mouvements sociaux, ancien esprit: une étude des structures anthropologiques de l'imaginaire des amapiens (Technical report).

Rose, A.A. (1948). The homes of homesick girls. The Journal of Child Psychiatry, 1(2), 181.

Rothenberg, R. (1989). The past is now the latest craze. The New York Times.

Rousseau, G.G., \& Venter, D.J.L. (1999). The influence of nostalgia on consumer preference. SA Journal of Industrial Psychology, 25(1), 36-42.

Schindler, R.M., \& Holbrook, M.B. (2003). Nostalgia for early experience as a determinant of consumer preferences. Psychology \& Marketing, 20(4), 275-302.

Shumaker, S.A., \& Taylor, R.B. (1983). Toward a clarification of people-place relationships: A model of attachment to place. Environmental Psychology: Directions and Perspectives, 2, 19-25.

Sierra, J.J., \& McQuitty, S. (2007). Attitudes and emotions as determinants of nostalgia purchases: An application of social identity theory. Journal of Marketing Theory and Practice, 15(2), 99-112.

Spearman, C. (1927). The abilities of man.

Stern, B.B. (1992). Historical and personal nostalgia in advertising text: The fin de siecle effect. Journal of Advertising, 21(4), 11-22.

Trilling, R.R. (2009). Aesthetics of nostalgia: Historical representation in Old English verse. University of Toronto Press.

Uzzell, D., Pol, E., \& Badenas, D. (2002). Place identification, social cohesion, and enviornmental sustainability. Environment and Behavior, 34(1), 26-53.

Vignolles, A. (2010). Influence de la perception nostalgique sur l'attachement à la marque, sur l'attitude à l'égard du produit et sur l'attitude à l'égard de la marquee. $\mathrm{PhD}$ thesis, Toulouse 1 Capitole.

Williams, D.R., Patterson, M.E., Roggenbuck, J.W., \& Watson, A.E. (1992). Beyond the commodity metaphor: Examining emotional and symbolic attachment to place. Leisure sciences, 14(1), 29-46. 


\section{APPENDIX A}

\section{Indicators of acculturation / nostalgia}

Indicators of origin country/ nostalgia

R1 : home language / nostalgia

R2 : the food of home country / nostalgia

R3 : the media of the country of origin/ nostalgia

$\mathrm{R} 4$ : the clothing of the country of origin / nostalgia

R5 : self-identification with the origin country/ nostalgia

R6 : the religion of the origin country/ nostalgia
Indicators of host country/ nostalgia

R7 : the language of the host country/ nostalgia

R8 : the host country's food / nostalgia

R9 : the clothing of the host country / nostalgia

R10 : self-identification with the host country / nostalgia

R11 : the religion of the host country / nostalgia 


\section{APPENDIX B}

\begin{tabular}{|c|c|c|c|c|}
\hline Independent variable & $\begin{array}{l}\text { Dependent } \\
\text { variable }\end{array}$ & $\begin{array}{l}\text { Levene Test } \\
\quad \text { Sig }\end{array}$ & $\begin{array}{l}\text { Anova } \\
\text { Sig }\end{array}$ & Comments \\
\hline Home language & Nostalgia & $0.061>0.05$ & $\begin{array}{l}0.008< \\
0,05\end{array}$ & $\begin{array}{l}\text { - Levene test is significant } \\
- \text { P of Anova is significant } \\
\text { - Home language } \nearrow \rightarrow \text { nostalgia } \nearrow\end{array}$ \\
\hline $\begin{array}{l}\text { The language } \\
\text { of the host country }\end{array}$ & Nostalgia & $0.572>0.05$ & $\begin{array}{l}0.804> \\
0.05\end{array}$ & $\begin{array}{l}\text { - Levene test is significant } \\
\text { - P of Anova in not significant } \\
\text { - there is no significant difference between } \\
\text { means }\end{array}$ \\
\hline $\begin{array}{l}\text { The food } \\
\text { of home country }\end{array}$ & Nostalgia & $0.087>0.05$ & $\begin{array}{l}0.016 \\
<0.05\end{array}$ & $\begin{array}{l}\text { - Levene test is significant } \\
- \text { P of Anova is significant } \\
\text { - the food of home country } \nearrow \rightarrow \text { nostalgia } \nearrow\end{array}$ \\
\hline $\begin{array}{l}\text { The host country's } \\
\text { food }\end{array}$ & Nostalgia & $0.121>0.05$ & $\begin{array}{l}0.385> \\
0.05\end{array}$ & $\begin{array}{l}\text { - Levene test is significant } \\
\text { - P of Anova in not significant } \\
\text { - there is no significant difference between } \\
\text { means }\end{array}$ \\
\hline $\begin{array}{l}\text { The media } \\
\text { of the country } \\
\text { of origin }\end{array}$ & Nostalgia & $0.779>0.05$ & $\begin{array}{l}0.017 \\
<0.05\end{array}$ & $\begin{array}{l}\text { - Levene test is significant } \\
-\mathrm{P} \text { of Anova is significant } \\
- \text { The media } \nearrow \rightarrow \text { nostalgia } \nearrow\end{array}$ \\
\hline $\begin{array}{l}\text { The clothing } \\
\text { of the country } \\
\text { of origin }\end{array}$ & Nostalgia & $0.008<0.05$ & & $\begin{array}{l}\text { - Levene test is not significant } \\
\text { - We cannot analyze the results } \\
\text { of the Anova }\end{array}$ \\
\hline $\begin{array}{l}\text { The clothing } \\
\text { of the host country }\end{array}$ & Nostalgia & $0.563>0.05$ & $\begin{array}{l}0.381> \\
0.05\end{array}$ & $\begin{array}{l}\text { - Levene test is significant } \\
\text { - P of Anova in not significant } \\
\text { - The clothing of the host country } \\
\text { has no impact on nostalgia } \\
\text { - there is no significant difference between } \\
\text { means }\end{array}$ \\
\hline $\begin{array}{l}\text { Self-identification } \\
\text { with the origin } \\
\text { country }\end{array}$ & Nostalgia & $0.761>0.05$ & $\begin{array}{l}0.000 \\
<0.05\end{array}$ & $\begin{aligned} &- \text { Levene test is significant } \\
&- \text { P of Anova is significant } \\
&- \text { Self-identification with the origin } \\
& \text { country } \nearrow \rightarrow \text { nostalgia } \nearrow\end{aligned}$ \\
\hline $\begin{array}{l}\text { Self-identification } \\
\text { with the host country }\end{array}$ & Nostalgia & $0.059>0.05$ & $\begin{array}{l}0.226> \\
0.05\end{array}$ & $\begin{array}{l}\text { - Levene test is significant } \\
\text { - P of Anova in not significant } \\
\text { - there is no significant difference between } \\
\text { means }\end{array}$ \\
\hline $\begin{array}{l}\text { The religion } \\
\text { of the origin country }\end{array}$ & Nostalgia & $0.103>0.05$ & $\begin{array}{l}0.000 \\
<0.05\end{array}$ & $\begin{array}{l}- \text { Levene test is significant } \\
- \text { P of Anova is significant } \\
- \text { The religion of the origin } \\
\text { country } \nearrow \rightarrow \text { nostalgia } \nearrow\end{array}$ \\
\hline $\begin{array}{l}\text { The religion } \\
\text { of the host country }\end{array}$ & Nostalgia & $0.06>0.05$ & $\begin{array}{l}0.808> \\
0.05\end{array}$ & $\begin{array}{l}\text { - Levene test is significant } \\
\text { - P of Anova in not significant } \\
\text { - there is no significant difference between } \\
\text { means }\end{array}$ \\
\hline
\end{tabular}

